\title{
Sistem Pendukung Keputusan Pemilihan Proyek Perangkat Lunak dengan Menggunakan Metode Weighted Product
}

\author{
Sri Widaningsih ${ }^{1}$, Sicha Bathin Ratusyaqina Manggala ${ }^{2}$ \\ ${ }^{1.2}$ Jurusan Teknik Informatika \\ Fakultas Teknik Universitas Suryakancana \\ sriwida@unsur.ac.id,ratusyaqinah20@gmail.com
}

\begin{abstract}
The use and utilization of information technology can increase the effectiveness and efficiency of every activity in companies and agencies. This has led to the increasing public interest in information technology products. In addition, the development of the digital era has become one of the factors for the increasing number of software houses being established. The problem arises if the software developer gets several requests for software development at the same time so that a priority must be made which order is made first. For decision making, a decision support system can be used using the MADM method, namely weighted product. There are several criteria that are considered, namely the contract value, the duration of the work, the complexity of the work, the use of resources, the technology used and the implementation and maintenance process. The calculation of this method is to multiply the criteria value of each project alternative that has been summarized by the criteria weight value. The resulting values are ranked and the relative preference values of the largest projects considered to be worked on first.
\end{abstract}

Key words : MADM, project, software, decision support system, weighted product

\begin{abstract}
Abstrak
Penggunaan dan pemanfaatan teknologi informasi dapat meningkatkan efektivitas dan efisensi pada setiap kegiatan di perusahaan maupun instansi. Hal tersebut menyebabkan semakin meningkatnya minat masyarakat terhadap produkproduk teknologi informasi Selain itu dengan berkembangnya era digital saat ini pun menjadi salah satu faktor semakin banyaknya software house yang didirikan. Permasalahan muncul jika pihak pengembang perangkat lunak mendapatkan beberapa permintaan pembuatan perangkat lunak dalam waktu yang bersaamaan sehingga harus dibuat prioritas pesanan mana yang dibuat terlebih dahulu. Untuk pengambilan keputusan tersebut dapat menggunakan Sistem Pendukung Keputusan dengan menggunakan metoda MADM yaitu weighted product. Terdapat beberapa kriteria yang dipertimbangkan yaitu nilai kontrak, durasi pengerjaan, kompleksitas pengerjaan, penggunaan sumber daya, teknologi yang digunakan dan proses implementasi dan pemeliharaan. Perhitungan metode ini adalah dengan mengalikan nilai kriteria setiap alternatif proyek yang telah dipangkatakan dengan nilai bobot kriteria. Nilai yang dihasilkan dirangking dan nilai preferensi relatif proyek terbesar yang dipertimbangkan untuk dikerjakan terlebih dahulu.
\end{abstract}

Kata kunci : MADM, proyek, perangkat lunak, sistem pendukung keputusan, weighted product

\section{Pendahuluan}

Era perkembangan teknologi informasi digital saat ini merupakan salah satu faktor pendorong munculnya bisnis pembuatan software atau perangkat lunak. Perusahaan pembuat software ini umumnya disebut sebagai software house atau startup. Dukungan pemerintah pun sangat besar dimana salah satu visi ekonomi digital Indonesia 2020 adalah menjadi "The Digital Energy of Asia". Ada dua jenis produk yang dihasilkan oleh suatu software house yaitu produk perangkat lunak yang dikembangkan atau dibuat secara umum atau produk yang dibuat berdasarkan proyek atau pesanan klien. Pengerjaan proyek perangkat lunak yang kurang direncanakan akan menyebabkan kekacauan. Banyak proyek perangkat lunak yang mengalami kegagalan karena perencanaan yang tidak dijalankan dengan baik. Hal ini terjadi karena penggelola proyek perangkat lunak masih beranggapan bahwa aktivitas utama proyek perangkat lunak adalah mendesain dan memprogram aplikasi perangkat lunak. Ini mengakibatkan pemrograman aplikasi perangkat lunak dikerjakan dengan tergesa-gesa [1]

Permasalahan lain yang muncul yaitu jika dalam satu waktu, pihak pengembang mendapatkan beberapa permintaan pembuatan perangkat lunak atau aplikasi dari berbagai pengguna. Tentunya hal tersebut merupakan peluang untuk pihak pengembang untuk mengembangkan usaha serta mengingkatkan kentungan. Namun, pengambilan keputusan pengerjaan proyek yang dilakukan secara tergesa-gesa tanpa pertimbangan yang matang serta hanya berorientasi pada keuntungan akan menimbulkan dampak negatif bagi pihak pengembang diantaranya adalah kualitasdan kesesuaian dari hasil pengerjaan akan berkurang. Hal ini akan berdampak pada tingkat kepuasan dari pihak pengguna atau klien. Penambahan pegawai (programmer) tentunya dapat 
menjadi solusi dalam permasalahan tersebut, namun hal tersebut akan menambah pengeluaran yang dikeluarkan oleh pihak pengembang itu sendiri sehingga dibutuhkannya pemecahan masalah yang akan meningkatkan keuntungan bagi pihak pengembang dengan memanfaatkan sumber daya manusia yang telah dimiliki. Oleh karena itu untuk menyelesaikan permasalahan tersebut, maka pihak pengembang diharuskan senantiasa memilih permintaan yang akan dikerjaan ataupun melakukan pengurutan permintaan yang harus dikerjaan agar seluruh pekerjaan dapat terselesaikan tepat waktu dan terjamin kualitasnya. Untuk melakukan hal tersebut, terdapat beberapa pertimbangan diantaranya adalah durasi pengerjaan, kompleksitas pekerjaan, penggunaan sumber daya, teknologi yang digunakan serta proses implementasi dan pemeliharaan (maintenance). Untuk mencapai hasil yang maksimal dan sesuai yang diharapkan, penggunaan sistem pendukung keputusan dalam pemilihan permintaan tersebut akan membantu pihak pengambil keputusan yaitu pengembang untuk dapat mengambil keputusan secara cepat dan tepat sehingga apa yang diharapkan dari pihak pengembang dan pengguna dapat terwujud dengan memaksimalkan sumber daya manusia yang ada namun tetap meningkatkan keuntungan bagi pihak pengembang. Hasil dari sistem pendukung keputusan bukanlah hal yang

menjadi patokan, pengambilan keputusan tetap berada pada pengambil keputusan yaitu pengembang perangkat lunak. Sistem pendukung keputusan hanya menghasilkan keluaran yang mengkalkulasi data-data sebagaimana pertimbangan seorang pengambil keputusan. Sehingga kerja pengambil keputusan dalam mempertimbangkan keputusan dapat dimudahkan [2]

Karena dalam pemilihan proyek perangkat lunak yang akan dikerjakan terlebih dahulu tersebut mempertimbangkan beberapa kriteria, maka pengambilan keputusan dalam penelitian ini berdasarkan pada Multi Attribute Decision Making (MADM). Metode Weighted Product (WP) merupakan salah satu metode MADM. Metode weighted product menggunakan Teknik perkalian untuk menghubungkan rating atribut, dimana rating tiap atribut harus dipangkatkan terlebih dahulu dengan bobot atribut yang bersangkutan [3] .

\section{Studi Literatur}

\subsection{Sistem Pendukung Keputusan}

Sistem Pendukung Keputusan (SPK) merupakan sistem informasi yang berbasis komputer yang fleksibel, interaktif dan dapat diadaptasi, yang dikembangkan untuk mendukung solusi untuk masalah manajemen spesifik yang tidak terstruktur. Sistem Pendukung Keputusan menggunakan data, memberikan antarmuka pengguna yang mudah dan dapat menggabungkan pemikiran pengambilan keputusan [4]. Terdapat empat buah komponen pembentuk sistem pendukung keputusan yaitu subsistem manajemen data, subsistem manajemen model, subsistem antarmuka dan subsistem manajemen berbasis pengetahuan [5].

Penelitian teknik-teknik MADM dalam pemilihan proyek sudah banyak dilakukan seperti pada SPK pemilihan proyek pengembangan sistem informasi [6] dengan beberapa kriteria yaitu benefit, permintaan, dampak organisasional, kesuksesan dan kebutuhan sumber yang dibagi lagi menjadi sub kriteria. Sedangkan [7] menggunakan metode TOPSIS untuk pemilihan proyek pembangunan.

\subsection{Weighted Product (WP)}

Metode weighted product merupakan salah satu metode MADM yang dikenalkan oleh Bridgman pada tahun 1922. Metoda ini memiliki kelebihan dan kekurangan. Beberapa kelebihan metode ini yaitu dilabeli untuk memecahkan masalah keputusan yang melibatkan tipe kriteria yang sama dan menggunakan nilai relatif sehingga menghilangkan masalah homogenitas. Sedangkan kekurangan metode ini yaitu mengarah kepada hasil yang tidak diinginkan sebagai prioritas atau mengurangi prioritas alternatif yang jauh dari nilai rata-rata [8] . Metode ini juga terbukti sebagai metode yang sangat andal untuk menyelesaikan pengambilan keputusan multi kriteria yang telah diuji untuk tiga hingga seratus kriteria.

Metode Weighted Product menggunakan perkalian untuk menghubungkan rating atribut, dimana rating setiap atribut harus dipangkatkan dulu dengan bobot atribut yang bersangkutan. Langkah-langkah dalam menggunakan metode ini adalah [9]:

1. Menentukan kriteria-kriteria yang akan dijadikan acuan dalam pengambilan keputusan.

2. Menentukan rating kecocokan setiap alternatif pada setiap kriteria.

3. Menentukan bobot preferensi tiap kriteria.

Mengalikan seluruh atribut bagi sebuah alternatif dengan bobot sebagai pangkat positif untuk atribut keuntungan dan bobot berpangkat negatif untuk atribut biaya.

Rumus preferensi untuk alternatif sebagai berikut :

$S_{i}=\prod_{j=1}^{n} x_{i j}{ }^{w_{j}}$

Dimana :

$\mathrm{S}_{\mathrm{i}}=$ preferensi alternatif dianalogikan sebagai vektor $\mathrm{S}$

$\mathrm{X}=$ nilai kriteria

$\mathrm{W}_{\mathrm{j}}=$ bobot kriteria

$i=\operatorname{alternatif}($ dimana $i=1,2, \ldots n)$

$\mathrm{j}=$ kriteria

$\mathrm{n}=$ banyaknya kriteria

$\sum W_{j}=1$

Nilai dimana $\mathrm{W}_{\mathrm{j}}$ memiliki pangkat bernilai positif untuk atribut keuntungan dan bernilai negatif untuk atribut biaya

Nilai preferensi relatif untuk alternatif yaitu : 


$$
V_{i}=\frac{S_{i}}{\sum S_{i}}
$$

Dimana :

$\mathrm{V}_{\mathrm{i}}=$ preferensi relatif alteranatif dianalogikan dengan vektor $\mathrm{V}$

\section{Metode Penelitian}

Rekayasa perangkat lunak yang digunakan untuk membangun sistem pendukung keputusan pemilihan proyek perangkat lunak ini mengikuti tahapan model waterfall. Terdapat beberapa tahapan dalam rekayasa ini yaitu communication, planning, modeling, construction, dan deployment [10] dan dapat dilihat pada gambar 1 .

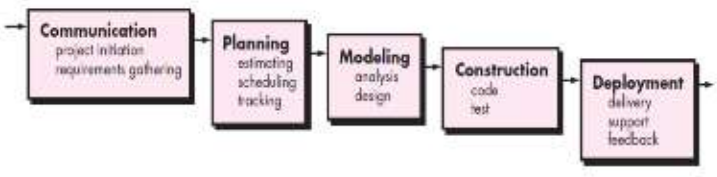

Gambar 1. Model Proses Waterfall

\section{Hasil dan Pembahasan}

\subsection{Tahapan Perhitungan Weighted Product}

Pemilihan proyek perangkat lunak dalam penelitian ini termasuk ke dalam multi atribut decision making (MADM) sehingga mengikuti beberapa tahapan dalam penyelesainnya. Pada gambar 2 berikut ini adalah tahapan MADM menggunakan metode weighted product.

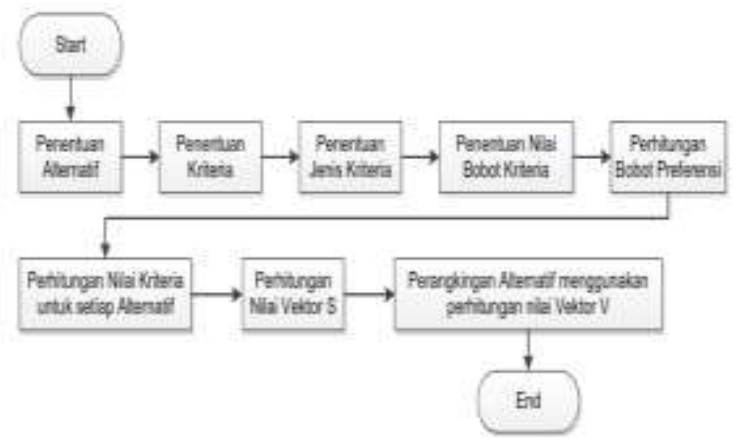

Gambar 2. Flowchart Perhitungan Metode Weighted Product

Berikut ini adalah contoh perhitugan weighted product untuk menentukan proyek perangkat lunak yang terlebih dahulu dikerjakan berdasarkan tahapan di atas .

\section{Penentuan alternatif}

Misalkan suatu perusahaan pengembang perangkat lunak mendapat beberapa proyek secara bersamaan , berasal dari empat klien berbeda dengan jenis proyek sebagai berikut :

Tabel 1. Penentuan Alternatif Proyek

\begin{tabular}{|c|lr|}
\hline Alternatif & \multicolumn{2}{|c|}{ Jenis Proyek } \\
\hline A1 & Sistem Informasi Akademik \\
\hline A2 & SPK Pemilihan Mahasiswa Teladan \\
\hline A3 & $\begin{array}{l}\text { Sistem Barcode Departemen } \\
\text { Hotpress }\end{array}$ \\
\hline A4 & Augmented Reality Lambang \\
\hline
\end{tabular}

Pancasila

2. Penentuan Kriteria

Tabel 2. Penentuan Kriteria

\begin{tabular}{|c|c|}
\hline Kriteria & Keterangan \\
\hline $\mathrm{C} 1$ & Nilai Kontrak (juta) \\
\hline $\mathrm{C} 2$ & Durasi Pengerjaan (minggu) \\
\hline $\mathrm{C} 3$ & $\begin{array}{l}\text { Kompleksitas Pekerjaan } \\
\text { Beberapa indikator yang digunakan } \\
\text { untuk kompleksitas pekerjaan : } \\
\text { a. Lingkup system } \\
\text { b. Jumlah modul yang } \\
\quad \text { dikerjakan } \\
\text { c. Fungsi yang disediakan } \\
\text { d. Masalah yang dipecahkan } \\
\text { e. Teknologi yang digunakan } \\
\text { Penilaian : } \\
\text { a. Mudah =1 } \\
\text { b. Sedang =2 } \\
\text { c. Sulit =3 }\end{array}$ \\
\hline $\mathrm{C} 4$ & Penggunaan sumber daya (orang) \\
\hline $\mathrm{C} 5$ & 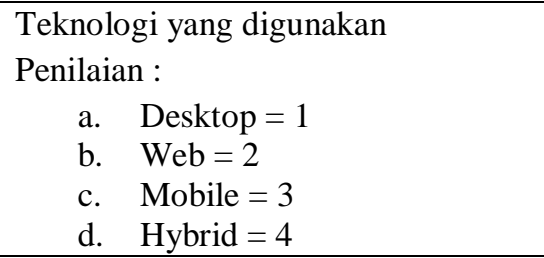 \\
\hline C6 & $\begin{array}{l}\text { Proses implementasi } \\
\text { pemeliharaan (minggu) }\end{array}$ \\
\hline
\end{tabular}

3. Penentuan Jenis Kriteria

Kategori di Metode Weighted Product, dibagi menjadi 2 :

a. Keuntungan (Benefit) yaitu semakin besar nilai maka semakin terpilih

b. Biaya (Cost) yaitu semakin kecil nilai maka semakin terpilih

Maka kategori untuk kriteria akan menjadi seperti ini

Tabel 3. Penentuan Jenis Kriteria

\begin{tabular}{|l|l|l|}
\hline Kriteria & Keterangan & Jenis \\
\hline C1 & Nilai kontrak (juta) & Benefit \\
\hline C2 & $\begin{array}{l}\text { Durasi pengerjaan } \\
\text { (minggu) }\end{array}$ & Cost \\
\hline C3 & Kompleksitas pekerjaan & Cost \\
\hline C4 & $\begin{array}{l}\text { Penggunaan Sumber daya } \\
\text { (orang) }\end{array}$ & Cost \\
\hline C5 & Teknologi yang digunakan & Cost \\
\hline C6 & $\begin{array}{l}\text { Proses implementasi dan } \\
\text { pemeliharaan }\end{array}$ & Cost \\
\hline
\end{tabular}

4. Penentuan Nilai Bobot Kriteria 
Untuk menentukan tingkat kepentingan setiap kriteria, juga dinilai dengan 1

sampai 5, yaitu:

$1=$ Sangat rendah,

$2=$ Rendah,

3 = Cukup,

Misalkan seorang pengembang perangkat lunak memberikan nilai tingkat kepentingan untuk setiap kriteria adalah sebagai berikut :

Tabel 4. Penentuan Bobot Kriteria

\begin{tabular}{|l|l|c|}
\hline Kriteria & Keterangan & Nilai \\
\hline C1 & Nilai kontrak (juta) & 2 \\
\hline C2 & Durasi pengerjaan (minggu) & 3 \\
\hline C3 & Kompleksitas pekerjaan & 5 \\
\hline C4 & $\begin{array}{l}\text { Penggunaan Sumber daya } \\
\text { (orang) }\end{array}$ & 3 \\
\hline C5 & Teknologi yang digunakan & 4 \\
\hline C6 & $\begin{array}{l}\text { Proses implementasi dan } \\
\text { pemeliharaan }\end{array}$ & 2 \\
\hline
\end{tabular}

5. Perhitungan Bobot Preferensi

$\sum W_{j}=1$

$W_{j}=\frac{W_{j}}{\sum W_{j}}$

$W=(2,3,5,3,4,2)$

$\sum W_{j}=19$

Bobot untuk setiap kriteria :

$W_{1}=\frac{2}{19}=0,11 ; W_{2}=\frac{3}{19}=0,16$

$W_{3}=\frac{5}{19}=0,26 ; W_{4}=\frac{3}{19}=0,16$

$W_{5}=\frac{4}{19}=0,21 ; W_{6}=\frac{2}{19}=0,11$

6. Perhitungan Nilai Kriteria Alternatif

Berikut ini nilai diberikan oleh project manager untuk setiap alternatif proyek yang akan dipilih berdasarkan setiap kriteria yang dipertimbangkan sebelumnya.

Tabel 5. Penilaian Alternatif Setiap Kriteria

\begin{tabular}{|c|c|c|c|c|c|c|}
\hline \multirow{2}{*}{ Alternatif } & \multicolumn{7}{|c|}{ Kriteria } \\
\cline { 2 - 7 } & $\boldsymbol{C} \boldsymbol{C}$ & $\boldsymbol{C 2}$ & $\boldsymbol{C 3}$ & $\boldsymbol{C 4}$ & $\boldsymbol{C 5}$ & $\boldsymbol{C 6}$ \\
\hline $\boldsymbol{A} \boldsymbol{I}$ & 4 & 8 & 2 & 5 & 2 & 2 \\
\hline $\boldsymbol{A} \boldsymbol{2}$ & 6 & 4 & 3 & 3 & 4 & 2 \\
\hline $\boldsymbol{A 3}$ & 2 & 2 & 1 & 2 & 1 & 1 \\
\hline $\boldsymbol{A} \boldsymbol{4}$ & 3 & 3 & 2 & 1 & 2 & 1 \\
\hline
\end{tabular}

7. Perhitungan Nilai Preferensi

$$
S_{i}=\prod_{j=1}^{n} x_{i j}{ }^{w_{j}}
$$

$S_{1}=\left(4^{0,11}\right)\left(8^{-0,16}\right)\left(2^{-0,26}\right)\left(5^{-0.16}\right)\left(2^{-0,21}\right)\left(2^{-0.11}\right)=0.86$

$S_{2}=\left(6^{0,11}\right)\left(4^{-0,16}\right)\left(3^{-0,26}\right)\left(3^{-0.16}\right)\left(4^{-0,21}\right)\left(2^{-0.11}\right)=0.68$

$S_{3}=\left(2^{0,11}\right)\left(2^{-0,16}\right)\left(1^{-0,26}\right)\left(2^{-0.16}\right)\left(1^{-0,21}\right)\left(1^{-0.11}\right)=0.43$

$S_{4}=\left(3^{0,11}\right)\left(3^{-0,16}\right)\left(2^{-0,26}\right)\left(1^{-0.16}\right)\left(2^{-0,21}\right)\left(1^{-0.11}\right)=0.43$

8. Perhitungan Nilai Preferensi Relatif

$$
\begin{gathered}
V_{i}=\frac{S_{i}}{\sum S_{i}} \\
V_{1}=\frac{0.86}{0.86+0.68+0.43+0.43}=0.36 \\
V_{2}=\frac{0.68}{0.86+0.68+0.43+0.43}=0.28 \\
V_{3}=\frac{0.43}{0.86+0.68+0.43+0.43}=0.18 \\
V_{4}=\frac{0.43}{0.86+0.68+0.43+0.43}=0.18
\end{gathered}
$$

9. Hasil Akhir

Sehingga dari hasil perhitungan diurutkan dari nilai terbesar sehingga proyek pertama yang dikerjakan yaitu sistem informasi akademik, SPK pemilihan mahasiswa teladan, Sistem barcode Departemen Hotpress dan terakhir adalah Augmented Reality lambang Pancasila

\subsection{Pemodelan Sistem}

Tahap pertama dalam membangun Sistem Pendukung Keputusan Pemilihan Proyek Perangkat Lunak yaitu dengan menganalisis sistem yang umumnya terjadi dalam pemilihan proyek perangkat lunak. Selanjutnya adalah membuat pemodelan sistem yang akan dibuat. Dalam penelitian ini pemodelan menggunakan UML ( unified modelling language) . Diagram-diagram yang digunakan diantaranya yaitu use case diagram, activity diagram, sequence diagram, dan class diagram.

\section{A. Use Case Diagram}

Use case diagram menggambarkan interaksi antara project manajer sebagai aktor dengan SPK Pemilihan Proyek Perangkat Lunak . Use case diagram ditunjukkan pada gambar 3 berikut . 


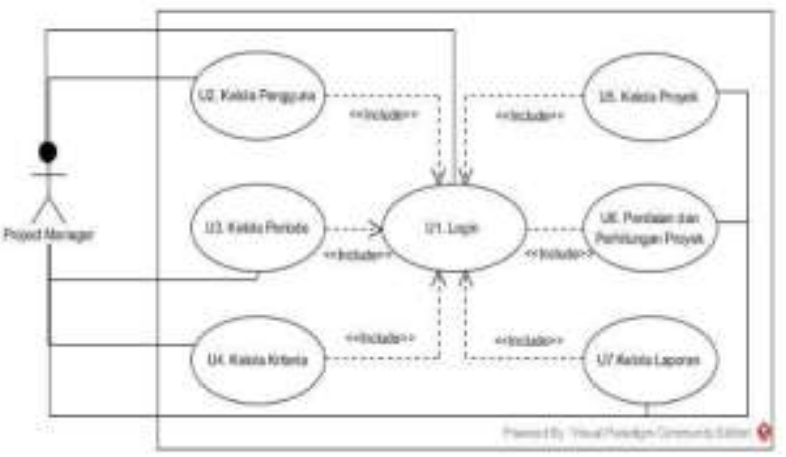

Gambar 3. Use Case Diagram SPK Pemilihan Proyek Perangkat Lunak

\section{B. Activity Diagram}

Activity diagram menggambarkan proses atau kegiatan yang terdapat di use case diagram SPK pemilihan proyek perangkat lunak. Terdapat enam activity diagram yang dibuat, diantaranya yaitu activity diagram kelola kriteria dan activity diagram penilaian dan perhitungan proyek

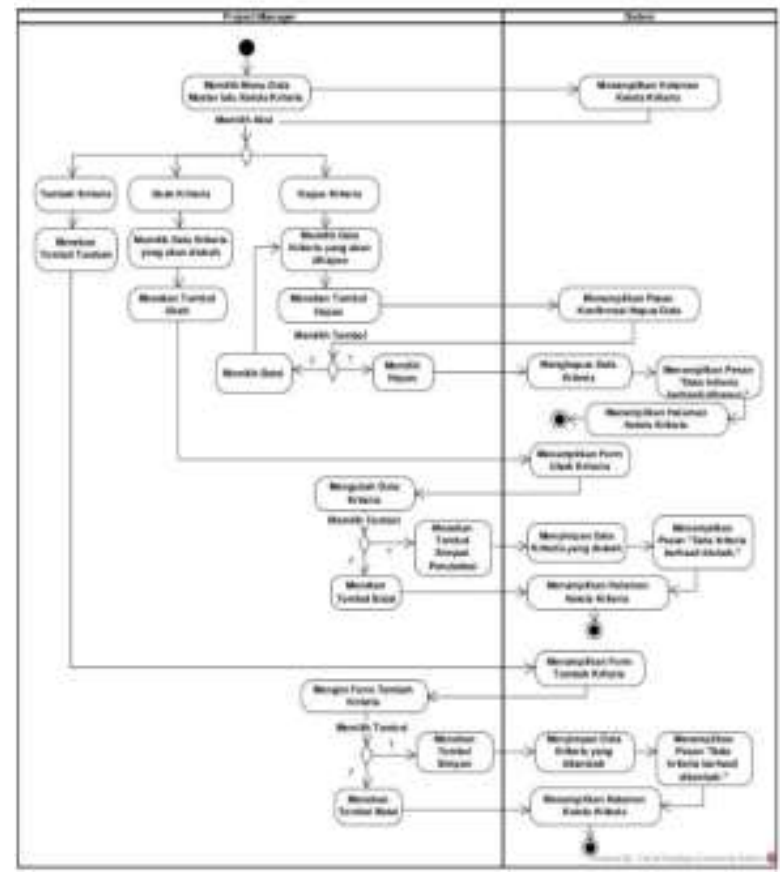

Gambar 4. Activity Diagram Kelola Kriteria

Gambar 4 menunjukkan activity diagram kelola kriteria dimana pada gambar tersebut terlihat aliran proses project manager saat memasukkan kriteriakriteria yang dipertimbangkan dalam pemilihan proyek.

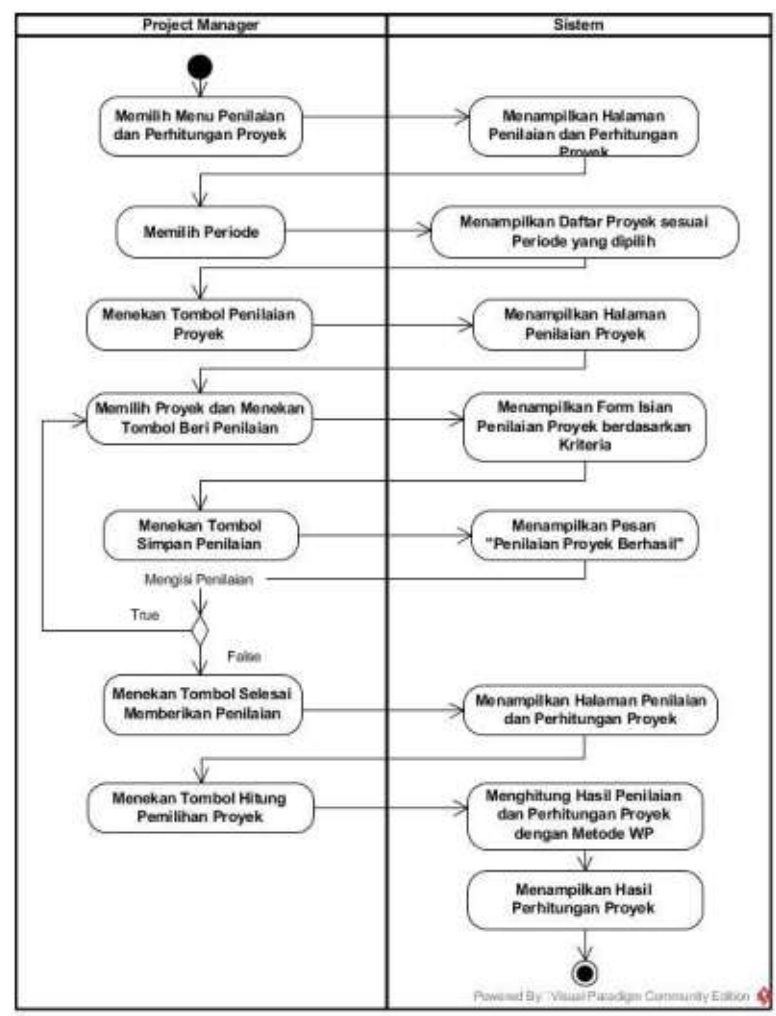

Gambar 5. Activity Diagram Penilaian dan Perhitungan Proyek

Pada gambar 5 digambarkan kegiatan yang dilakukan oleh project manager dalam menilai kriteria setiap alternatif dan sistem melakukan perhitungan weighted product untuk menghasilkan nilai preferensi relatif setiap alternatif proyek.

\section{Sequence Diagram}

Kelakuan objek dan interaksi antar objek pada SPK pemilihan proyek perangkat lunak dapat digambarkan dengan sequence diagram. Sequence diagram yang dibuat berdasarkan pada use case sebelumnya. Pada gambar 6 ditunjukkan sequence diagram kelola kriteria sedangkan pada gambar 7 ditunjukkan sequence diagram penilaian dan perhitungan proyek 


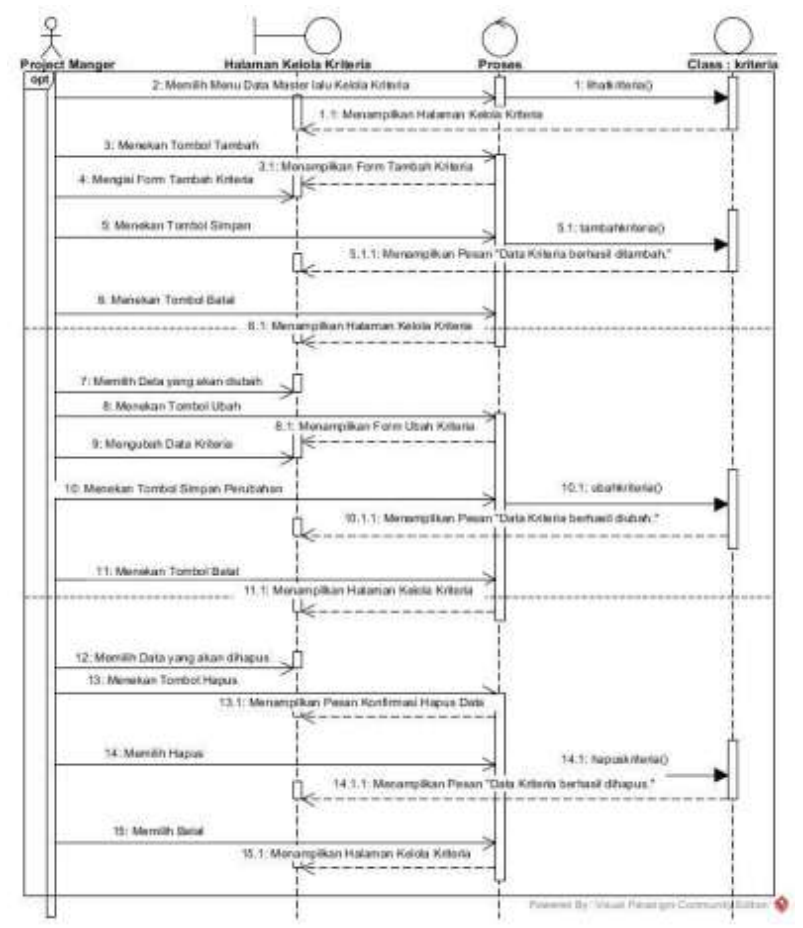

Gambar 6. Sequence Diagram Kelola Kriteria

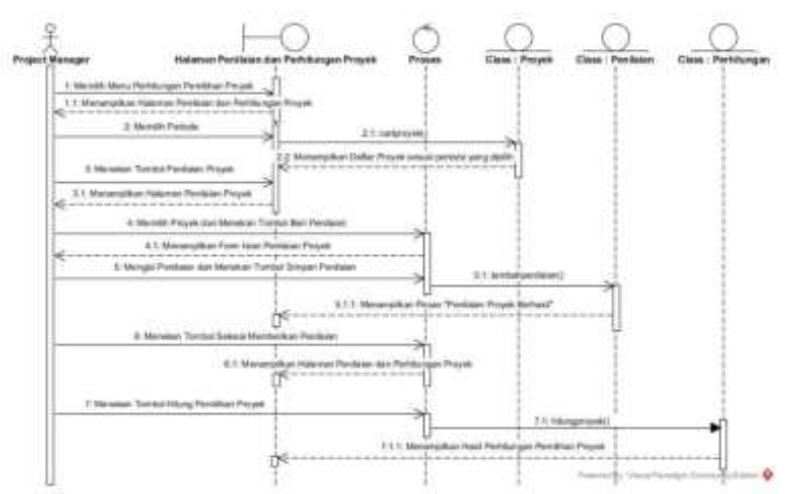

Gambar 7. Sequence Diagram Penilaian dan Perhitungan Proyek

\section{Class Diagram}

Class diagram yang ditunjukkan pada gambar 8 menggambarkan struktur-struktur kelas yang membentuk SPK pemilihan proyek perangkat lunak. Setiap kelas memiliki atribut dan metode tersendiri.

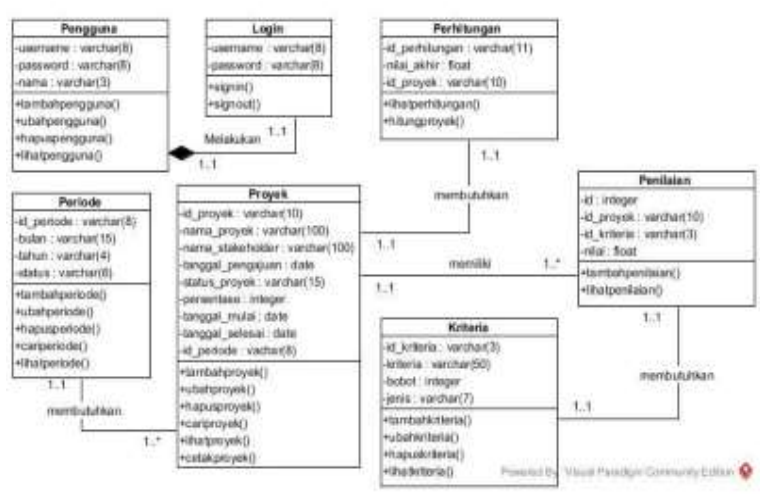

Gambar 8. Class Diagram

4.3 Pemodelan Basis Data

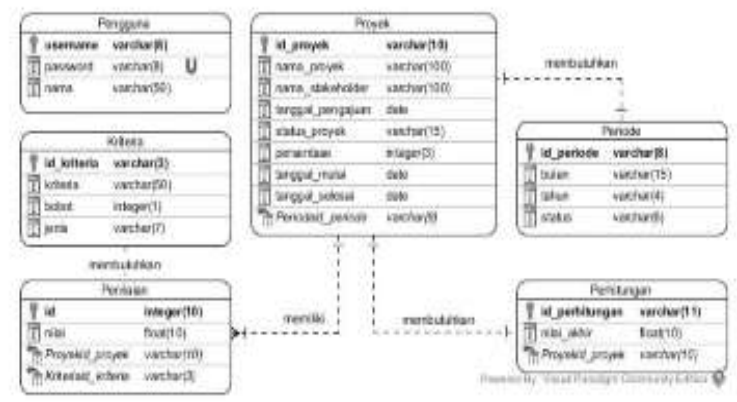

Gambar 9. Entity Relationship Diagram

Pemodelan basis data pada penelitian ini menggunakan model entitiy relationhip diagram (ERD). Pada gambar 9 menunjukkan hubungan antar entitas yang akan digunakan di basis data. Beberapa entitas yang terdapat pada ERD SPK pemilihan proyek perangkat lunak yaitu pengguna, proyek, kriteria, penilaian , periode ,dan perhitungan.

\subsection{Perancangan Sistem}

Perancangan sistem dilakukan berdasarkan pada pemodelan yang telah dilakukan sebelumnya. Perancangan SPK dilakukan dengan merancang tabel basis data yang akan digunakan serta antarmuka sistem

\subsection{Implementasi}

Dari pemodelan dan perancangan SPK Pemilihan Proyek Perangkat Lunak yang telah dilakukan, maka tahap selanjutnya yaitu melakukan implementasi dengan membuat produk dengan menggunakan bahasa pemrograman delphi XE. Berikut ini adalah beberapa hasil antarmuka SPK yang telah dibangun. 


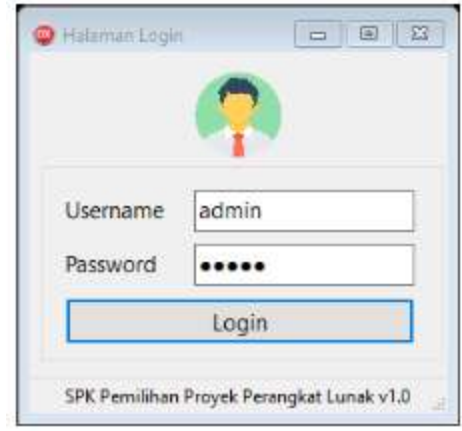

Gambar 10. Antarmuka Halaman Login

Halaman login ditunjukkan pada gambar 10 yaitu halaman yang digunakan oleh user dalam proses login kedalam sistem. User yaitu project manager memasukan username dan password untuk proses autentifikasi.

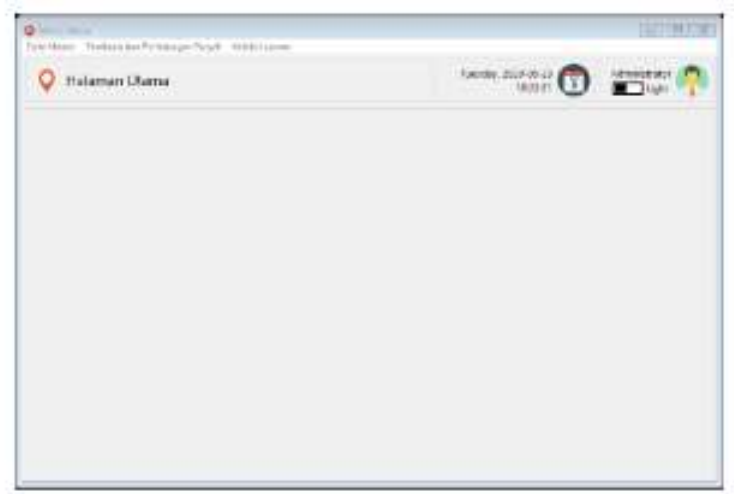

Gambar 11. Antarmuka Halaman Utama

Gambar 11 menunjukkan antarmuka halaman utama dari sistem dimana dapat diakses setelah berhasil proses login. Pada halaman ini terdapat beberapa menu yang berisi tahapan proses weighted product.

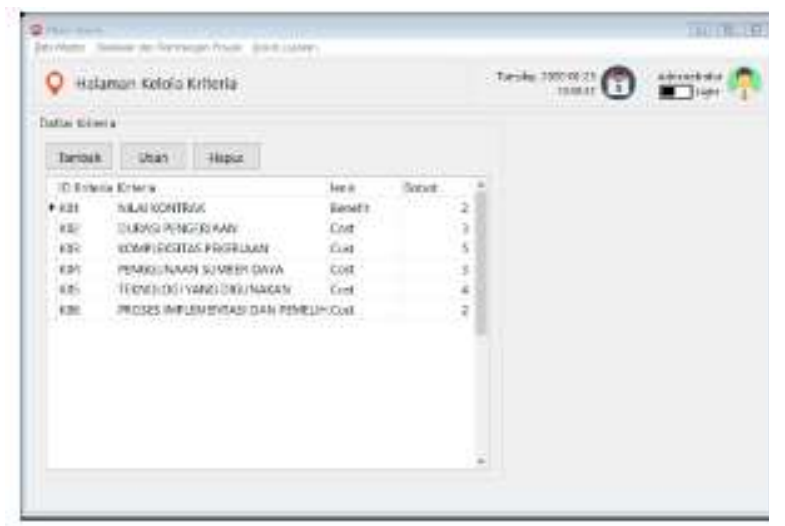

Gambar 12. Antarmuka Halaman Kelola Kriteria

Antarmuka halaman Kelola kriteria pada gambar 12 merupakan halaman dimana user memasukkan kriteriakriteria yang digunakan untuk pemilihan proyek perangkat lunak beserta dengan jenis keputusan dan penilaian prefernsi setiap kriteria yang nantinya digunakan untuk pembobotan kriteria.

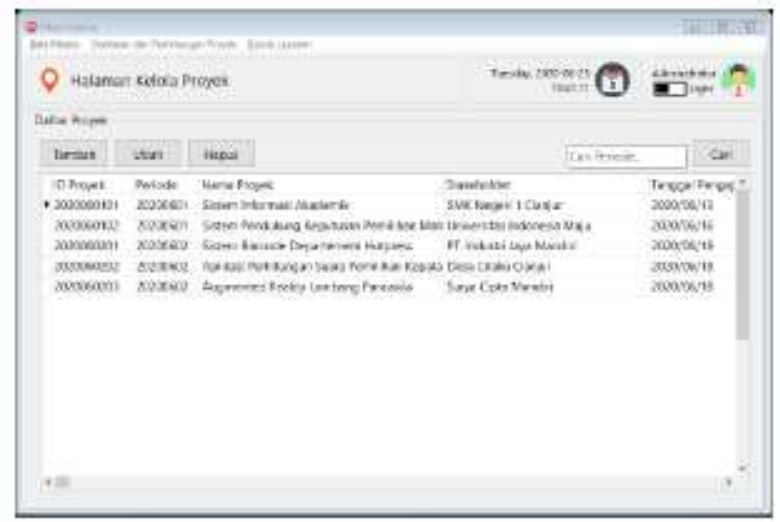

Gambar 13. Antarmuka Halaman Kelola Proyek

Antarmuka halaman kelola proyek pada gambar 13 merupakan halaman dimana user memasukkan alternatif proyek-proyek masuk dan dipertimbangkan untuk dikerjakan . Pengisian nama proyek juga dengan klien dan tanggal masuk permintaan klien.

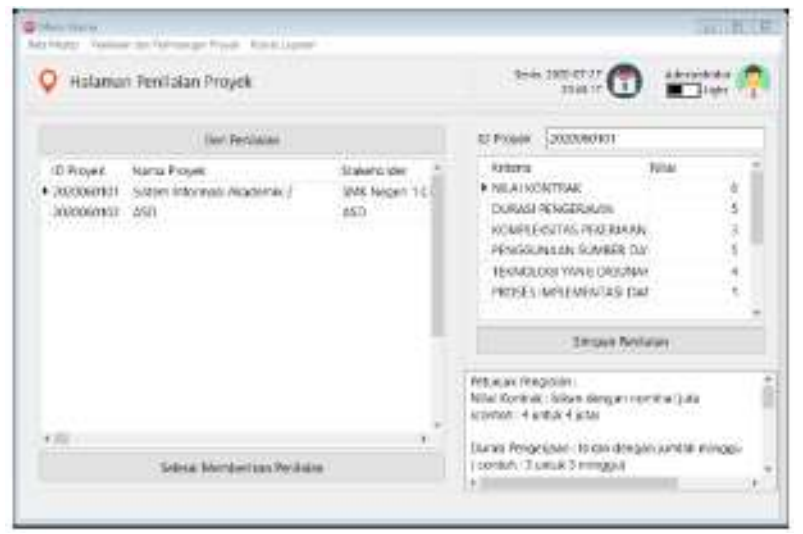

Gambar 14. Antarmuka Halaman Penilaian Proyek

Antarmuka halaman penilaian proyek pada gambar 14 merupakan halaman yang digunakan oleh user untuk memasukkan nilai-nilai setiap alternatif untuk setiap kriteria. Nilai-nilai yang dimasukkan berdasarkan pada tabel 3 penentuan kriteria.

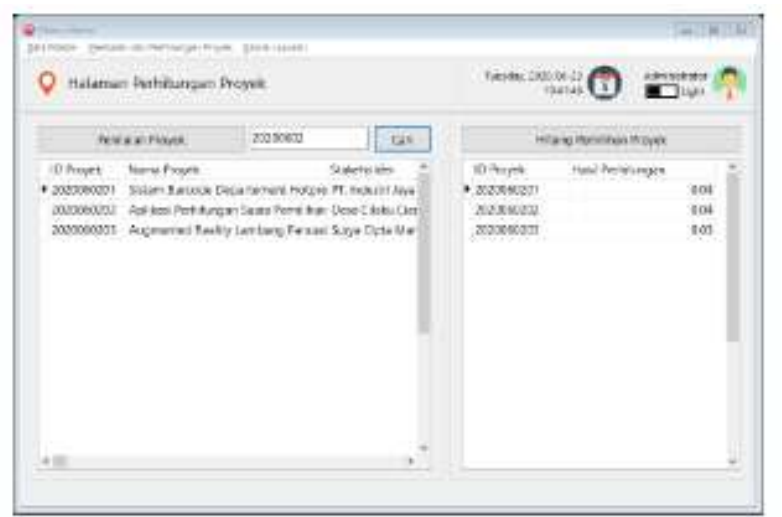

Gambar 15 . Antarmuka Halaman Perhitungan 
Halaman perhitungan proyek pada gambar 15 merupakan halaman dimana user dapat melakukan perhitungan pemilihan proyek menggunakan metode weighted product. Pada halaman ini akan ditampilkan nilai akhir setiap preferensi relatif setiap alternatif proyek perangkat lunak yang nantiya akan diranking dari nilai terbesar. Hasil ini lah yang akan menjadi pertimbangan project manager untuk memilih proyek perangakat lunak mana yang diprioritaskan untuk dikerjakan pertama.

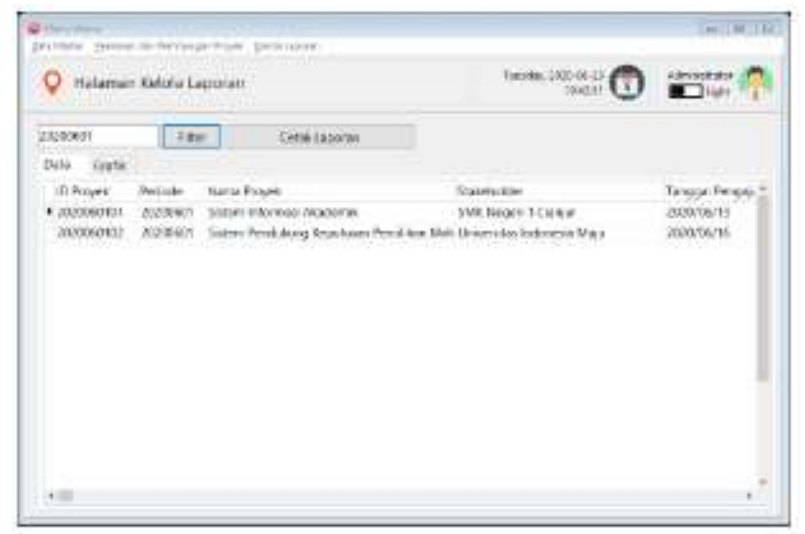

Gambar 16. Antarmuka Halaman Kelola Laporan

Antarmuka halaman kelola laporan pada gambar 16 berisi mengenai laporan dari pemilihan proyek.

\section{Kesimpulan}

1. Sistem pendukung keputusan pemilihan proyek perangkat lunak ini menggunakan metode MADM yaitu weighted product dengan mempertimbangkan beberapa kriteria yaitu nilai kontrak, durasi pengerjaan, kompleksitas pekerjaan, penggunaan sumber daya, teknologi yang digunakan, serta waktu implementasi dan maintenance.

2. Sistem pendukung keputusan ini digunakan pihak pengembang (developer)untuk dapat membantu dalam mengambil keputusan secara cepat dan tepat dalam memilih proyek perangkat lunak yang akan diambil dan dikerjaan.

3. Sistem pendukung keputusan ini digunakan pihak pengembang (developer) untuk dapat melakukan pengurutan proyek perangkat lunak yang harus dikerjaan agar seluruh pekerjaan dapat terselesaikan dengan tepat waktu sehingga apa yang diharapkan dari pihak developer dan pengguna dapatterwujud.

4. Hasil yang didapatkan dari sistem berupa pendukung keputusan, keputusan tetap ditentukan oleh pengambil keputusan.

\section{Daftar Pustaka}

[1] Munir, Manajemen Proyek Perangkat Lunak, Bandung: UPI Press, 2015.

[2] Wibowo, Manjemen Kinerja, Jakarta: PT. Raja Grafindo Persada, 2011.

[3] S. Kusumadewi, Fuzzy Multi - Attribute Decison Making, Yogyakarta: Graha Ilmu, 2006.

[4] E. Turban, R. Sharda and D. Delen, Decision Support and Business. Intelligence Systems 9th Editon, Pearson Education Inc, 2011.

[5] E. Turban, R. Sharda, J. E. Aronson and T. P. Liang, Decision Support and Business Intelligence Systems. 8th Edition., New Jersey: Prentice Hall, Inc., 2011.

[6] Y. Y. Wibisono, "Sistem Pendukung Keputusan untuk Pemilihan Proyek Pengembangan Sistem Informasi," in Seminar Nasional Aplikasi Teknologi Informasi (SNATI), Yogyakarta, 2006.

[7] E. Deni, "Sistem Pendukung Keputusan Pemilihan Proyek Pembangunan Menggunkan Metode Technique For Order Of Preference By Similarity To Ideal Solution (TOPSIS).," Skripsi Thesis Institut Teknologi Nasional Malang, Malang, 2018.

[8] A. Kumara, B. Sahb, A. Singhc, Y. Denga, X. Hea, P. Kumarb and R. Bansald, "A review of multi criteria decision making (MCDM) towards sustainable renewable energy," Renewable and Sustainable Energy Reviews, vol. 69, pp. 596-609, 2017.

[9] D. Nofriansyah, Konsep Data Mining VS Sistem Pendukung Keputusan, Yogyakarta: Deepublish, 2014.

[10] R. S. Pressman, Rekayasa Perangkat Lunak, Yogyakarta: Andi, 2015. 